\title{
PEMANFAATAN TANAMAN OBAT KELUARGA OLEH ORANG TUA UNTUK KESEHATAN ANAK DI DUWET NGAWEN KLATEN
}

\author{
Susilo Yulianto, Ag. Kirwanto \\ Kementerian Kesehatan Politeknik Kesehatan Surakarta Jurusan Jamu
}

\begin{abstract}
Utilization of TOGA, Parent, Child Health. Medicinal Plants Family (TOGA) is an alternative treatment that has been carried out by the Indonesian people traditionally. The success of TOGA utilization is strongly influenced by the public's knowledge about the benefits of each type of medicinal plants, especially medicinal plants that have been studied empirically. It is also influenced by how the use of each of medicinal plants for a variety of different diseases. This study aims to determine the utilization of medicinal plants by parents for child health in Duwet, Ngawen, Klaten. This research method is descriptive, with a sample of 53 respondents were taken by simple random sampling technique. Data collection conducted direct interviews with respondents and open observation. Research instrument used was a questionnaire. The result showed that all respondents have ever used medicinal plants for their health. The conclusion of this study is the use of medicinal plants by parents for child health in Duwet, Ngawen, Klaten still needs to be improved further by providing the knowledge, awareness, willingness and ability of the parents.
\end{abstract}

Keywords: Utilization Of TOGA, Parent, Child Health

Abstrak: Pemanfaatan TOGA, Orang Tua, Kesehatan Anak. Tanaman Obat Keluarga (TOGA) merupakan salah satu alternatif pengobatan yang telah lama dilakukan oleh masyarakat Indonesia secara tradisional. Keberhasilan pemanfaatan TOGA ini sangat dipengaruhi oleh pengetahuan masyarakat mengenai manfaat dari setiap jenis tanaman yang berkhasiat obat terutama tanaman obat yang telah diteliti secara empiris. Selain itu juga dipengaruhi oleh cara penggunaan masing-masing tanaman obat untuk berbagai penyakit yang berbeda. Penelitian ini bertujuan untuk mengetahui pemanfaatan tanaman obat keluarga oleh orang tua untuk kesehatan anak di Duwet, Ngawen, Klaten. Metode penelitian ini adalah deskriptif, dengan sampel sebanyak 53 responden yang diambil dengan teknik sampel acak sederhAana. Pengumpulan data dilakukan secara wawancara langsung kepada responden dan observasi terbuka. Instrument penelitian yang digunakan ialah kuesioner. Dari hasil penelitian didapatkan bahwa seluruh responden pernah memanfaatkan tanaman obat keluarga untuk kesehatan anaknya. Kesimpulan penelitian ini yaitu pemanfaatan tanaman obat keluarga oleh orang tua untuk kesehatan anak di Duwet, Ngawen, Klaten masih perlu ditingkatkan lagi dengan cara memberikan pengetahuan, kesadaran, kemauan dan kemampuan para orang tua.

Kata Kunci: Pemanfaatan TOGA, Orang Tua, Kesehatan Anak. 


\section{PENDAHULUAN}

Meningkatnya

kesadaran

masyarakat akan kesehatan, berpengaruh pula pada penggunaan obat herbal yang berasal dari tumbuhan dengan cara tradisional dan alami yang sudah dimanfaatkan oleh masyarakat Indonesia dari sejak nenek moyang kita. Hal ini banyak dilakukan masyarakat karena khasiatnya sudah terbukti dapat menyembuhkan penyakit, lebih murah dan efek sampingnya lebih kecil dibandingkan dengan obat-obat konvensional. Tanaman obat berasal dari tumbuh-tumbuhan baik dari akarnya, daun, buah, bunga dan kulit kayunya.

Pada usia anak-anak masih terjadi pertumbuhan dan perkembangan, yang merupakan usia emas perkembangan. Seluruh organ tubuhnya belum optimal bila dibandingkan dengan usia dewasa dan daya tahan tubuhnya juga masih labil. Oleh karena itu untuk mengoptimalkan pertumbuhan, perkembangan dan meningkatkan daya tahan tubuhnya dibutuhkan lingkungan, perilaku, asupan gizi, pendidikan, pola asuh dan perlindungan kesehatan yang baik.

Pada umumnya masalah kesehatan yang sering dialami anak-anak adalah kurang gizi, pola makan, kurang olah raga dan gangguan kesehatan (Yusuf, 2002: 157). Gizi seimbang akan mempengaruhi pertumbuhan dan perkembangan anak dapat optimal. Banyaknya makanan instan yang cepat saji yang banyak disukai anakanak, sangat berpengaruh terhadap kesehatan anak sehingga anak mudah sakit.

Bila anak mengalami gangguan kesehatan, para orang tua akan sesegera mungkin untuk mencari pengobatan yang dianggap dapat segera menyembuhkan penyakit anak tersebut, diantaranya ke rumah sakit, ke puskesmas, ke dokter, ke bidan atau menggunakan tanaman obat keluarga (TOGA).

\section{METODE PENELITIAN}

Jenis penelitian yang digunakan adalah penelitian deskriptif dengan pendekatan kuantitatif. Rancangan menggunakan cross sectional. Populasi dalam penelitian ini ialah seluruh orang tua yang memiliki anak-anak di Duwet, Ngawen, Klaten.Pengambilan sampel dalam penelitian ini menggunakan purposive sampling, yaitu teknik penentuan sampel dengan pertimbangan tertentu (Soegiono, 2011). Sampel pada penelitian ini adalah 53 responden

\section{HASIL PENELITIAN}

Dari 53 responden yang diteliti, jumlah responden dengan umur $>40$ tahun merupakan kelompok umur yang terbanyak yaitu sebanyak 40 orang $(75,5$ $\%$ ), umur 30 - 40 tahun sebanyak 9 orang (17\%) dan yang terkecil adalah umur < 30 tahun sebanyak 4 orang $(7,5 \%)$.

\section{Tabel 1}

\section{Distribusi Frekuensi Umur Orang Tua}

\begin{tabular}{|c|c|c|c|}
\hline No & $\begin{array}{l}\text { Umur } \\
\text { Responden }\end{array}$ & Jumlah & $\begin{array}{l}\text { Prosentase } \\
(\%)\end{array}$ \\
\hline 1. & $<30$ Tahun & 4 & 7,5 \\
\hline 2. & 30 - 40 Tahun & 9 & 17 \\
\hline 3. & $>40$ Tahun & 40 & 75,5 \\
\hline & TOTAL & 53 & 100 \\
\hline
\end{tabular}
pendidikan SD sebanyak 37 orang $(69,8$ $\%$ ), sedangkan yang terkecil pada responden dengan tingkat pendidikan Perguruan Tinggi yaitu sebanyak 2 orang $(3,8 \%)$, SMP sebanyak 3 orang $(5,7 \%)$ dan SMA 11 orang $(20,7 \%)$. 
Tabel 2

Distribusi Frekuensi Tingkat Pendidikan

\begin{tabular}{clcc}
\hline No & $\begin{array}{l}\text { Tingkat } \\
\text { pendidikan }\end{array}$ & Jumlah & $\begin{array}{l}\text { Prosentase } \\
(\%)\end{array}$ \\
\hline 1. & SD & 37 & 69,8 \\
2. & SMP & 3 & 5,7 \\
3. & SMA & 11 & 20,7 \\
4. & PT & 2 & 3,8 \\
\hline & TOTAL & 53 & 100 \\
\hline & Responden & dengan jenis kelamin
\end{tabular}
perempuan sebanyak 36 orang $(67,9 \%)$, sedangkan responden laki-laki sebanyak 17 orang $(32.1 \%)$.

\section{Tabel 3}

Distribusi Frekuensi Jenis Kelamin

\begin{tabular}{llcc}
\hline No & Jenis & Jumlah & Prosentase (\%) \\
& Kelamin & & \\
\hline 1. & Laki-laki & 17 & 32,1 \\
2. & Perempuan & 36 & 67,9 \\
\hline & TOTAL & 53 & 100 \\
\hline
\end{tabular}

Anak yang pernah mengalami ganggguan kesehatan sebanyak 45 anak $(84,9 \%)$, dan yang tidak pernah mengalami gangguan kesehatan sebanyak 8 anak $(15,1 \%)$.

\section{Tabel 4}

Distribusi Frekuensi Gangguan Kesehatan

\begin{tabular}{llcc}
\hline \multicolumn{3}{c}{ Kesehatan } \\
\hline No & $\begin{array}{l}\text { Anak yang } \\
\text { pernah } \\
\text { mengalami } \\
\text { gangguan } \\
\text { kesehatan }\end{array}$ & & \\
& & \\
\hline 1 & Ya & 45 & 84,9 \\
2 & Tidak & 8 & 15,1 \\
\hline Total & & 53100 \\
53 & & & \\
\hline
\end{tabular}
penyakit parotitis sebanyak 38 anak $(71,7 \%)$ dan anak yang tidak pernah mengalami parotitis sebanyak 15 anak $(28,3 \%)$.

\section{Tabel 5}

Distribusi Frekuensi Penyakit Parotitis

\begin{tabular}{cccc}
\hline NO. & $\begin{array}{l}\text { Penyakit parotitis } \\
\text { yang pernah dialami } \\
\text { anak }\end{array}$ & F & $\%$ \\
\hline 1. & Ya & 38 & 71,7 \\
2. & Tidak & 15 & 28,3 \\
\hline & Total & 53 & 100 \\
\hline
\end{tabular}

Anak yang diberikan bawang merah ketika panas sebanyak 42 anak $(79,2 \%)$ dan responden yang tidak memberikan bawang merah ketika anak panas sebanyak 11 anak $(20,8 \%)$.

\section{Tabel 6}

Distribusi Frekuensi pemberian bawang merah

\begin{tabular}{cccc}
\hline No & $\begin{array}{c}\text { Pemberian Bawang } \\
\text { Merah }\end{array}$ & F & $\%$ \\
\hline 1. & Ya & 42 & 79,2 \\
2. & Tidak & 11 & 20,8 \\
\hline & Total & 53 & 100 \\
\hline
\end{tabular}

Orang tua yang memberikan jeruk nipis ketika anak mengalami batuk sebanyak 42 responden $(79,2 \%)$ dan yang tidak memberikan jeruk nipis ketika anak mengalami batuk sebanyak 11 responden $(20,8 \%)$.

\section{Tabel 7}

Distribusi Frekuensi Pemberian Jeruk

\begin{tabular}{lccc}
\multicolumn{4}{c}{ Nipis } \\
\hline No & $\begin{array}{c}\text { Pemberian Jeruk } \\
\text { Nipis }\end{array}$ & F & $\%$ \\
\hline 1. & Ya & 42 & 79,2 \\
2. & Tidak & 11 & 20,8 \\
\hline & Total & 53 & 100 \\
\hline
\end{tabular}

Orang tua yang memberikan jahe ketika anak mengalami pilek sebanyak 29 responden $(54,7 \%)$ dan orang tua yang tidak memberikan memberikan jahe ketika anak mengalami pilek 24 responden $(45,3 \%)$.

Tabel 8

\begin{tabular}{|cccc}
\multicolumn{4}{c}{ Distribusi Frekuensi Pemberian Jahe } \\
\hline No & Pemberian Jahe & F & $\%$ \\
\hline 1. & Ya & 29 & 54,7 \\
2. & Tidak & 24 & 45,3 \\
\hline & Total & 53 & 100 \\
\hline
\end{tabular}


Orang tua yang memberikan kencur ketika anak mengalami radang tenggorokan sebanyak 39 responden $(73,6 \%)$ dan orang tua yang tidak memberikan memberikan kencur ketika anak mengalami radang tenggorokan 14 responden $(26,4 \%)$.

Tabel 9

Distribusi Frekuensi Pemberian

Kencur

\begin{tabular}{llcc}
\hline No. & Pemberian Kencur & F & $\%$ \\
\hline 1. & Ya & 39 & 73,6 \\
2. & Tidak & 14 & 26,4 \\
\hline \multicolumn{2}{r}{ Total } & 53 & 100 \\
\hline
\end{tabular}

Orang tua yang memberikan temu giring ketika anak mengalami cacingan sebanyak 14 responden $(26,4 \%)$ dan orang tua yang tidak memberikan temu giring ketika anak mengalami cacingan sebanyak 39 responden $(73,6 \%)$.

\section{Tabel 10}

Distribusi Frekuensi Pemberian Temu Giring

\begin{tabular}{|c|c|c|c|}
\hline No & $\begin{array}{l}\text { Pemberian Temu } \\
\text { Giring }\end{array}$ & $\mathrm{F}$ & $\%$ \\
\hline 1. & $\mathrm{Ya}$ & 14 & 26,4 \\
\hline 2. & Tidak & 39 & 73,6 \\
\hline & Total & 53 & 100 \\
\hline
\end{tabular}

Orang tua yang memberikan daun sirih ketika anak mengalami mimisan sebanyak 50 responden $(94,3 \%)$ dan orang tua yang tidak memberikan daun sirih ketika anak mengalami mimisan sebanyak 3 responden $(5,7 \%)$.

\section{Tabel 11}

Distribusi Frekuensi Pemberian Daun Sirih

\begin{tabular}{|c|c|c|c|}
\hline No & $\begin{array}{l}\text { Pemberian Daun } \\
\text { Sirih }\end{array}$ & $\mathrm{F}$ & $\%$ \\
\hline 1. & $\mathrm{Ya}$ & 50 & 94,3 \\
\hline 2. & Tidak & 3 & 5,7 \\
\hline & Total & 53 & 100 \\
\hline
\end{tabular}

Orang tua yang memberikan daun jambu biji ketika anak mengalami diare sebanyak 43 responden $(81,1 \%)$ dan orang tua yang tidak memberikan daun jambu biji ketika anak mengalami diare sebanyak 10 responden $(18,9 \%)$.

Tabel 12

Distribusi Frekuensi Pemberian Daun Jambu Biji

\begin{tabular}{|c|c|c|c|}
\hline No & $\begin{array}{c}\text { Pemberian Daun } \\
\text { Jambu Biji }\end{array}$ & $\bar{F}$ & $\%$ \\
\hline 1. & Ya & 43 & 81,1 \\
\hline \multirow[t]{2}{*}{2.} & Tidak & 10 & 18,9 \\
\hline & Total & 53 & 100 \\
\hline
\end{tabular}
pepaya ketika anak mengalami sembelit sebanyak 48 responden $(90,6 \%)$ dan orang tua yang tidak memberikan daun jambu biji ketika anak mengalami diare sebanyak 5 responden $(9,4 \%)$.

\section{Tabel 13}

Distribusi Frekuensi Pemberian Pepaya

\begin{tabular}{|c|c|c|c|}
\hline No & Pemberian Pepaya & $\mathrm{F}$ & $\%$ \\
\hline 1. & $\mathrm{Ya}$ & 48 & 90,6 \\
\hline 2. & Tidak & 5 & 9,4 \\
\hline & Total & 53 & 100 \\
\hline
\end{tabular}

Orang tua yang memberikan daun sirih ketika anak mengalami belekan/mata merah sebanyak 37 responden $(69,8 \%)$ dan orang tua yang tidak memberikan daun sirih ketika anak mengalami belekan/mata merah sebanyak 16 responden $(30,2 \%)$.

\section{Tabel 14}

\section{Distribusi Frekuensi Pemberian Daun}

\begin{tabular}{|c|c|c|c|}
\hline \multicolumn{4}{|c|}{ Sirih } \\
\hline No & $\begin{array}{l}\text { Pemberian Daun } \\
\text { Sirih }\end{array}$ & $\mathrm{F}$ & $\%$ \\
\hline 1. & Ya & 37 & 69,8 \\
\hline 2. & Tidak & 16 & 30,2 \\
\hline & Total & 53 & 100 \\
\hline
\end{tabular}
Orang tua yang memberikan lengkuas ketika anak mengalami gatalgatal sebanyak 21 responden $(39,6 \%)$ dan orang tua yang tidak memberikan lengkuas ketika anak mengalami gatalgatal sebanyak 32 responden $(60,4 \%)$. 
Tabel 15

Distribusi Frekuensi Pemberian Lengkuas

\begin{tabular}{llcc}
\hline No & Pemberian Lengkuas & $\mathrm{F}$ & $\%$ \\
\hline 1. & Ya & 21 & 39,6 \\
2. & Tidak & 32 & 60,4 \\
\hline \multicolumn{2}{c}{ Total } & 53 & 100 \\
\hline & Orang & tua & yang
\end{tabular}

memberikan beluntas ketika anak mengalami cacar sebanyak 13 responden $(24,5 \%)$ dan orang tua yang tidak memberikan beluntas ketika anak mengalami cacar sebanyak 40 responden $(75,5 \%)$

\section{PEMBAHASAN}

Memberikan temu giring ketika anak mengalami cacingan sebanyak 14 responden dengan persentase $26,4 \%$ dan orang tua yang tidak memberikan temu giring ketika anak mengalami cacingan sebanyak 39 responden dengan persentase $73,6 \%$.

Daun sirih ketika anak mimisan sebanyak 50 responden dengan persentase 94,3\% dan yang tidak memberikan daun sirih ketika anak mengalami mimisan sebanyak 3 responden dengan persentase $5,7 \%$.

Pemberian daun jambu biji ketika anak mengalami diare sebanyak 43 responden dengan persentase $81,1 \%$ dan orang tua yang tidak memberikan daun jambu biji ketika anaknya mengalami diare sebanyak 10 responden dengan persentase $18,9 \%$.

Memberikan pepaya ketika anaknya mengalami sembelit sebanyak 48 responden dengan persentase $90,6 \%$ dan yang tidak memberikan pepaya ketika anaknya mengalami sembelit sebanyak 5 responden dengan persentase $9,4 \%$.

Pemberian daun sirih ketika anaknya mengalami belekan/mata merah sebanyak 37 responden dengan persentase
$69,8 \%$ dan orang tua yang tidak memberikan daun sirih ketika anaknya mengalami belekan/mata merah sebanyak 16 responden dengan persentase 30,2\%.

Memberikan lengkuas ketika anaknya mengalami gatal-gatal sebanyak 21 responden dengan persentase 39,6\% dan orang tua yang tidak memberikan lengkuas ketika anaknya mengalami gatalgatal sebanyak 32 responden dengan persentase $60,4 \%$.

Beluntas ketika anaknya mengalami cacar sebanyak 13 responden dengan persentase $24,5 \%$ dan orang tua yang tidak memberikan beluntas ketika anaknya mengalami cacar sebanyak 40 responden dengan persentase $75,5 \%$.

Pemberian daun pegagan ketika anaknya mengalami campak sebanyak 7 responden dengan persentase $13,2 \%$ dan orang tua yang tidak memberikan daun pegagan ketika anaknya mengalami campak sebanyak 46 responden dengan persentase $86,8 \%$.

\section{KESIMPULAN DAN SARAN}

Tanaman obat keluarga yang sering dimanfaatkan orang tua untuk kesehatan anaknya yaitu bawang merah, jeruk nipis, jahe, kencur, temu giring, daun sirih, daun jambu biji, pepaya, lengkuas, beluntas, daun pegagan, kunyit dan mengkudu. Masalah kesehatan yang sering dialami anak yaitu parotitis (gondongan), panas, batuk, pilek, radang tenggorokan, cacingan, mimisan, diare, sembelit, belekan/mata merah, gatal-gatal, cacar, campak (gabagen) dan amandel.

Orang tua yang mampu meracik dengan benar tanaman obat keluarga untuk mengatasi ketika anak mengalami masalah kesehatan hanya $20,8 \%$ dan orang tua yang tidak mampu meracik dengan benar tanaman obat keluarga 
untuk mengatasi ketika anak mengalami masalah kesehatan 79,2\%.

Berdasarkan hasil penelitian yang telah dilakukan, maka peneliti memberikan saran sebagai berikut:

1. Pemanfaatan tanaman obat keluarga oleh orang tua untuk mengobati anak yang mengalami masalah kesehatan masih banyak digunakan. Oleh karena itu sebaiknya kepada para orang tua yang memiliki anak pada khususnya dan masyarakat pada umumnya membudi dayakan dan mengembangkan tanaman obat keluarga secara mandiri di halaman dan pekarangannya masing-masing, khususnya yang bermanfaat untuk kesehatan anak dan kesehatan masyarakat pada umumnya.

2. Bagi para orang tua yang memiliki anak sebaiknya meningkatkan kesadaran, kemauan dan kemampuan dalam memanfaatkan tanaman obat keluarga untuk kesehatan anaknya, dengan cara lebih banyak lagi menambah wawasan, ilmu pengetahuan, teknologi dan informasi tentang tanaman obat keluarga hingga meracik, mengkonsumsi dan khasiatnya.

3. Para orang tua dalam memanfaatkan tanaman obat kelurga untuk kesehatan anak masih sebatas untuk mengobati bila anak mengalami masalah kesehatan, padahal yang paling baik yaitu memanfaatkan tanaman obat keluarga sejaka anak masih dalam kondisi sehat dengan memberikan tanaman-tanaman obat keluarga yang berkhasiat untuk meningkatkan kesehatan anak (promotif) dan yang berkhasiat untuk mencegah terjadinya berbagai penyakit pada anak (preventif).

\section{DAFTAR RUJUKAN}

Ngastiyah, 2005. Perawatan Anak Sakit. Edisi 2. Jakarta : EGC

Sulastomo, 2000. Manajemen kesehatan, Jakarta : Gramedia Pustaka Utama

Supriyadi, 2001. Tumbuhan Obat Indonesia Penggunaan dan Khasiatnya, Jakarta : Pustaka. Populer

Suriadi,Yuliani R, 2001. Asuhan Keperawatan pada Anak, Jakarta : CV Agung Seto

Wijayakusuma HMH, Dalimartha S dan Wirian AS. 1993. Tanaman Berkhasiat Obat di. Indonesia. Jilid II, Jakarta : Pustaka Kartini

Wijayakusuma,HMH, 2007. Penyembuhan dengan Mengkudu. Jakarta : Penerbit Sarana Pustaka Afiat

Widyawati, 1999. Tanaman Obat Tradisional, Puslitbang Tanaman Pangan, Bogor. 